\title{
DERECHO PENAL SUSTANTIVO Y EFECTOS EN EL TIEMPO DE LA SENTENCIA DEL TRIBUNAL CONSTITUCIONAL QUE DECLARA LA INCONSTITUCIONALIDAD DE UN PRECEPTO LEGAL
}

\author{
Felipe Caballero Brun*
}

\begin{abstract}
RESUMEN
El presente artículo analiza las interpretaciones posibles de la cláusula de exclusión del efecto retroactivo contenida en el inciso segundo del artículo 94 de la Constitución Politica de la República y las implicancias que dichas interpretaciones podrían tener para el principio constitucional de retroactividad penal favorable.
\end{abstract}

\section{RETROACTIVIDAD DE LA LEY PENAL FAVORABLE - DERECHO PENAL - JURISDICCIÓN CONSTITUCIONAL}

\section{Criminal law and effects over time of the Constitutional Court's decision declaring the unconstitutionality of a legal precept}

\author{
Abstract
}

This article analyzes some interpretations of the clause excluding retroactive effect, contained in the second subparagraph of article 94 of the Chilean Constitution, and the implications that those interpretations might have on the constitutional principle of favorable criminal retroactivity.

\author{
FAVORABLE RETROACTIVITY OF CRIMINAL ACTS - \\ CRIMINAL LAW - JUDICIAL REVIEW
}

\footnotetext{
* Abogado. Postgraduado en Constitución y Derecho Penal. Becario de investigación doctoral adscrito al Área de Derecho Penal de la Universidad de Salamanca (Programa doctoral "Aportaciones de la Política Criminal a las Reformas Penales Iberoamericanas"). Se deja constancia que el presente trabajo ha sido realizado con el apoyo del Programa Alban, Programa de becas de alto nivel de la Unión Europea para América Latina, beca N E04D031062CL. Correo electrónico: fcb@usal.es Artículo recibido el 22 de septiembre de 2006 y aceptado para su publicación por el Comité Editorial el 6 de noviembre de 2006.
} 


\section{Planteamiento Del problema}

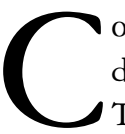
on las reformas introducidas por la ley $\mathrm{N}^{\mathrm{o}} 20.050^{1}$ a la Constitución Política de la República -en adelante CPR- las funciones y el rol que desempeñaba el Tribunal Constitucional (en lo sucesivo TC) han cambiado cualitativa y sustancialmente. ${ }^{2}$ En lo que aquí interesa, y desde la fecha en que entran en vigencia las aludidas reformas (27/02/2006), el TC posee jurisdicción constitucional para declarar la inaplicabilidad (art. $93 \mathrm{~N}^{\circ} 6^{\circ} \mathrm{CPR}$ ) de un precepto legal a un caso concreto (con efecto inter partes) y para declarar -con efectos generales (erga omnes) - la inconstitucionalidad (art. $93 \mathrm{~N}^{\circ} 7^{\circ} \mathrm{CPR}$ ) de aquel mismo precepto legal que (previamente) ha sido declarado inaplicable.

Estas reformas suponen sin duda un paso trascendente dentro de la inacabada evolución del Estado democrático de Derecho. De ser originariamente el TC un ente cuya tarea principal era dirimir conflictos entre órganos constitucionales y ejercer un control de constitucionalidad de carácter preventivo, en la fase de formación de la ley, se ha transformado en el soporte esencial que garantiza -frente a las demás normas jurídicas- la supremacía de la Constitución para defender y promover la dignidad humana y los derechos intrínsecos a ella. ${ }^{3}$ Se ha convertido en el verdadero garante de la Carta Fundamental frente al legislador o bien, como ha sido calificado recientemente por algún autor, en el "más notable defensor" de los derechos asegurados por la Constitución. ${ }^{4}$

Conforme a la actual redacción de la CPR, el inciso segundo de su art. 94 establece que la sentencia del TC que declare la inconstitucionalidad de un precepto legal no tendrá efecto retroactivo, y que el referido precepto legal se entenderá derogado desde la publicación de la sentencia respectiva en el diario oficial. ${ }^{5}$ De lo señalado en la norma

\footnotetext{
${ }^{1}$ Publicada en el diario oficial del 26/08/2005.

${ }^{2}$ Nos referimos específicamente a aquellas relevantes para este trabajo que se incorporan por los $\mathrm{N}^{\circ} \mathrm{s}$ 42 y 43 del art. $1^{\circ}$ de dicha ley.

${ }^{3}$ En este sentido Cea Egaña, José Luis, "Imagen del Juez y de la Justicia Constitucional en América Latina”, ponencia a la V Conferencia Iberoamericana de Justicia Constitucional, 21/08/2006, p. 10. Puede consultarse en http://www.tribunalconstitucional.cl/site/documentos/documentos.html

${ }^{4}$ Así Fernández González, Miguel Angel, La Sentencia del Tribunal Constitucional, su Eventual Carácter Vinculante y la Inserción en las Fuentes del Derecho, en Estudios Constitucionales No1/2006, p. 132.

${ }^{5}$ Art. 94. "Contra las resoluciones del Tribunal Constitucional no procederá recurso alguno, sin perjuicio de que puede, el mismo Tribunal, conforme a la ley, rectificar los errores de hecho en que hubiere incurrido. "Las disposiciones que el Tribunal declare inconstitucionales no podrán convertirse en ley en el proyecto o decreto con fuerza de ley de que se trate".

"En el caso del $\mathrm{N}^{\circ} 16^{\circ}$ del artículo 93, el decreto supremo impugnado quedará sin efecto de pleno derecho, con el solo mérito de la sentencia del Tribunal que acoja el reclamo. No obstante, el precepto declarado inconstitucional en conformidad a lo dispuesto en los numerales 2, 4 ó 7 del artículo 93, se entenderá derogado desde la publicación en el Diario Oficial de la sentencia que acoja el reclamo, la que no producirá efecto retroactivo".

"Las sentencias que declaren la inconstitucionalidad de todo o parte de una ley, de un decreto con fuerza de ley, de un decreto supremo o auto acordado, en su caso, se publicarán en el Diario Oficial dentro de los tres días siguientes a su dictación”.
} 
antes citada pareciera que, en principio, los efectos derogatorios de la sentencia estimatoria de la inconstitucionalidad de un precepto legal -que pudiere incidir en la materia penalmente prohibida, la responsabilidad penal o la pena- no podrían aplicarse a hechos acaecidos con antelación a la publicación de la misma en el diario oficial. ${ }^{6}$ Por consiguiente cabría colegir que si del efecto derogatorio derivado de la mencionada sentencia del TC se configura - desde la perspectiva del derecho penal sustantivo- una situación jurídica más favorable para el imputado que aquella deducible durante la vigencia del precepto legal declarado inconstitucional, entonces el juzgador penal no podría aplicarla al caso concreto cuando éste supone la valoración de hechos acaecidos con antelación al momento en que la sentencia del TC produce sus efectos. En otras palabras, el juez penal -respecto de hechos ocurridos antes de la sentencia del TC- no podría resolver el juzgamiento sometido a su conocimiento sobre la base de los efectos derogatorios sobre un precepto legal que resultan favorables al imputado. Así el principio constitucional de retroactividad de la ley penal favorable, en el caso de las sentencias de inconstitucionalidad, perdería toda su eficacia y función garantizadora.

Estudiar y analizar si una interpretación con las consecuencias jurídicas precedentemente descritas es constitucionalmente admisible y compatible con los principios generales del derecho y, en particular, con el de retroactividad de la ley penal favorable constituye el objeto de este trabajo.

Hacemos presente que consideramos la retroactividad de la ley penal favorable como un principio y no como una excepción a la general irretroactividad que se acostumbra a predicar de las leyes penales. ${ }^{7}$ Ello por cuanto estimamos que -frente al problema de la sucesión temporal de leyes susceptibles de ser aplicadas en el juzgamiento penal de un hecho- la solución derivada del bloque constitucional de derechos fundamentales ${ }^{8}$ es siempre la aplicación de aquella norma que resulte más favorable para el destinatario de la sanción (independientemente de su vinculación temporal, anterior o posterior, con la comisión

${ }^{6}$ Esta misma idea pareciera surgir del art. $47 \mathrm{~W}$ que se pretende introducir en la Ley Orgánica del Tribunal Constitucional chileno; el cual dispone: "La sentencia que declare la inconstitucionalidad de todo o parte de un precepto legal, la publicará, en extracto, el Diario Oficial dentro de los tres días siguientes a su dictación. Desde esa fecha, el precepto quedará derogado, lo que no producirá efecto retroactivo". Cfr. Mensaje del Presidente de la República No 432-353 de 07/12/2005, con el que inicia un Proyecto de Ley que modifica la Ley $\mathrm{N}^{\circ} 17.997$, Orgánica Constitucional del Tribunal Constitucional.

${ }^{7}$ Así también (en la doctrina española) Huerta Tocildo; Susana, El Derecho Fundamental a la Legalidad Penal, en REDC N³9/1993, p. 100, Boix Reig; Javier, El Principio de Legalidad en la Constitución, en AA. VV., "Repercusiones de la Constitución en el Derecho Penal", Publicaciones de la Universidad de Deusto, Bilbao, 1983, p. 73 y Octavio de Toledo y Ubieto; Emilio, "Sobre el Concepto de Derecho Penal”, Universidad Complutense de Madrid, 1981, p. 325. En la doctrina italiana cfr. Ferrajoli; Luigi, "Derecho y Razón (Teoría del Garantismo Penal)", Trotta, Madrid, 1995, p. 705.

${ }^{8} \mathrm{El}$ concepto de bloque constitucional de derechos fundamentales lo hemos tomado de Nogueira Alcalá; Humberto, Elementos del Bloque Constitucional del Acceso a la Jurisdicción y Debido Proceso Proveniente de la Convención Americana de Derechos Humanos, en EC N 1/2004, p. 124. Específicamente, para el derecho a la retroactividad de la ley penal favorable, dicho bloque está conformado por los arts. $19 . \mathrm{N}^{\circ} 3$, inc. $7^{\circ} \mathrm{CPR}$, 15.1 del Pacto Internacional de Derechos Civiles y Políticos y 9 de la Convención Americana de Derechos Humanos. 
o del hecho). De este modo la retroactividad de la ley penal favorable se convierte en una institución mucho más relevante que una mera excepción a la irretroactividad; y, por lo tanto, pasa a constituirse en la base fundamentadora que guía de modo general las respuestas constitucionalmente posibles de ser ensayadas en los problemas de intertemporalidad que se presentan en el derecho penal. ${ }^{9}$

Asimismo queremos advertir que -sin perjuicio de que el art. 94 CPR también señala que los efectos de la sentencia serán los mismos para el caso de la estimatoria de inconstitucionalidad de autos acordados y decretos con fuerza de ley- en nuestro análisis no haremos alusión a estas singulares normas jurídicas. Toda vez que, conforme al principio de legalidad en sentido estricto (art. $19 \mathrm{~N}^{\circ} 3$, incisos $7^{\circ}$ y $8^{\circ}$ y art. 64 inciso $2^{\circ}$ de la CPR), las mismas no poseen idoneidad para ser fuente creadora de delitos y penas; y por ello el problema antes descrito no podría, en puridad, llegar a verificarse respecto a ellas.

\section{LOS EFECTOS EN EL TIEMPO \\ DE LA SENTENCIA DE INCONSTITUCIONALIDAD}

En general la doctrina constitucional ha intentado determinar el efecto temporal de la sentencia estimatoria de inconstitucionalidad recurriendo a elaboraciones dogmáticas construidas a partir de la diferenciación entre nulidad y anulabilidad. ${ }^{10}$ Así cuando el juez constitucional declara inconstitucional una norma legal, lo que en rigor haría sería dictar una sentencia declarativa de nulidad en relación a la norma afectada. De este modo

\footnotetext{
${ }^{9}$ Para un abordaje en profundidad de este principio (en la doctrina comparada) vid. Frígols i Brines; Eliseu, "El Principio de Irretroactividad y la Sucesión de Leyes Penales (Una Perspectiva desde el Derecho Comparado)", Ed. Jurídica Continental, San José de Costa Rica, 2002, Jeschek; Hans-Heinrich y Weigend; Thomas, "Tratado de Derecho Penal Parte General”, 5ª ed., Comares, Granada, 2002, pp. 147-152, Lascuraín Sánchez; Juan Antonio, "Sobre la Retroactividad Favorable”, Civitas, Madrid, 2000, Pérez Royo; Fernando, La Aplicación Retroactiva de la Ley Penal Más Favorable en los Casos de Modificaciones en la Normativa Tributaria, en Revista Técnica Tributaria No 43/1998, pp. 75-88, Rudolphi; Hans-Joachim, Comentario al $\S 2$, en AA. VV., "Systematischer Kommentar zum Strafgesetzbuch", AT, (6 ed) Metzner, Frankfurt, 1997, pp. 20-31, Eser; Albin, Comentarios a los $\$ \$ 1$ y 2, en Schönke-Schröder, "Strafgesetzbuch Kommentar", (25 a ed.) Beck, Munich, 1997, pp. 49-61, Huerta Tocildo; Susana, op. cit., pp. 81-113, Leone; Mauro, "Il Diritto Penale nel Tempo (I, Aspetti Constituzionali del Principio di Irretroattività)”, Casa Editrice Dott. Eugenio Jovene, Napoli, 1980 y Siniscalco; Marco, "Irretroattività delle Leggi in Materia Penale", Dott. Giuffré Editore, Milano, 1987.

10 "Se dice que las decisiones judiciales que se pronuncian sobre la nulidad tienen efectos ex tunc, mientras las decisiones judiciales que determinan su anulabilidad producen efectos ex nunc. Se refieren estas expresiones a las posibles consecuencias que la decisión judicial pueda tener sobre los efectos anteriores a ella que hayan sido producidos por los actos invalidados. Mientras que la expresión ex tunc implica la eficacia retroactiva de la sentencia de anulación, la locución ex nunc implica la carencia de esa eficacia, con lo que los efectos anteriores a la decisión no resultarán afectados, quedando consolidados, y teniendo ahora el pronunciamiento una eficacia meramente prospectiva”; cfr. Iniesta Delgado, Juan José y Fernández Salmerón, Manuel; Naturaleza y Efectos de las Sentencias de Anulación Recaídos en Procesos contra Normas: La Invalidez en

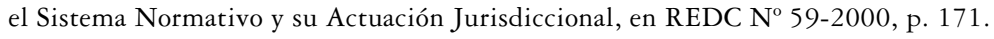


la norma sería nula de pleno derecho a los efectos de su aplicación y la declaración de nulidad tendría claros efectos retroactivos (ex tunc), en cuanto la norma legal dejaría de aplicarse a los hechos acaecidos bajo su amparo. Por otro lado, desde la perspectiva de la anulabilidad, se plantea que lo pretendido ante la jurisdicción constitucional es sólo la anulación de una ley inconstitucional y con ello la sentencia de inconstitucionalidad tendría un carácter meramente constitutivo que sólo podría proyectar sus efectos hacia el futuro (ex nunc). La nulidad se correspondería con los efectos que se derivan de un sistema de control de constitucionalidad difuso, propio del Comm1 on Law; y la anulabilidad con los efectos derivados de un sistema concentrado de control de constitucionalidad como el establecido originalmente en 1920 en la Constitución de Austria. ${ }^{11}$

Según este planteamiento los efectos en el tiempo de la sentencia de inconstitucionalidad dependerían, ante todo, de la propia naturaleza jurídica que se le atribuyera a la resolución estimatoria (declarativa o constitutiva); naturaleza que sería capaz de condicionar y determinar los referidos efectos con una automaticidad mecánica. ${ }^{12}$ Así el trinomio nulidad, sentencia declarativa y efectos ex tunc formarían parte de una particular estructura dogmática que sería perfectamente diferenciable de la otra estructura dogmática posible, compuesta, a su vez, por el trinomio anulabilidad, sentencia constitutiva y efectos ex nunc.

Sin perjuicio de la trascendencia analítica y explicativa que un modelo dogmático como el señalado representa en la conformación de una teoría de la jurisdicción constitucional y de un Derecho Procesal Constitucional, ${ }^{13}$ no se puede compartir que la posible extensión hacia el pasado de la eficacia erga omnes de la decisión de inconstitucionalidad sea una exigencia impuesta por la automaticidad del propio sistema: nulidad o anulabilidad.

Menos aún, si se tiene presente que esta bipartición (nulidadlanulabilidad) -en su versión moderna ${ }^{14}$ no es originaria del derecho público sino una categorización propia del pandectismo alemán ${ }^{15}$ que, con su marcada influencia en la elaboración del $B G B,{ }^{16}$ logró consolidar una estructura explicativa simple y clara en torno a la ineficacia de los actos jurídicos; la cual, después de la codificación decimonónica, sería recepcionada

${ }^{11}$ Sobre esta diferenciación, sus orígenes y alcances vid. Almagro Nosete, José; "Justicia Constitucional”, $2^{a}$ ed., Tirant Lo Blanch, Valencia, 1989, pp. 261 y ss. Entre nosotros cfr. Nogueira Alcalá, Humberto; $L a$ Sentencia Constitucional en Chile: Aspectos Fundamentales sobre su Fuerza Vinculante, en Estudios Constitucionales $\mathrm{N}^{\circ}$ 1/2006, pp. 102-103.

${ }^{12}$ Para una crítica profunda a esta pretendida automaticidad con que operarían (específicamente) los efectos inherentes al modelo de anulabilidad -en la perspectiva del derecho constitucional italiano-cfr. Martín de la Vega, Augusto; "La Sentencia Constitucional en Italia", Centro de Estudios Políticos y Constitucionales, Madrid, 2003, pp. 332 y ss.

${ }^{13}$ Sin perjuicio de tener opinión sobre el tema, debido a las características de este trabajo, obviamente no podemos profundizar en este momento la discusión aún 1p. 161-171. Nuestra opinión quedará expuesta más adelante (vid. infra IV.1.1.).

${ }^{14}$ Nos referimos a moderna en el sentido contrapuesto a la teorización propia del derecho romano.

${ }^{15}$ Para una visión representativa de esta escuela cfr. el trabajo de Windscheid; Bernhard, "Lehrbuch des Pandektenrechts”, I, Frankfurt am Mein, 1887 (específicamente sobre teoría de la nulidad), pp. 246 y ss.

${ }^{16}$ Abreviación de Bürgerliches Gesetzbuch (Código Civil alemán). 
por el Derecho Administrativo. ${ }^{17}$ Por lo tanto no parece metodológicamente aceptable trasladar sin reparos al derecho constitucional una construcción teórica inspirada en añejos esquemas jurídico-privados ${ }^{18}$ y que sus consecuencias, además, nunca han sido adoptadas en todos sus extremos por el derecho positivo. ${ }^{19}$

De ahí que plantear el problema de los efectos temporales de la sentencia de inconstitucionalidad en clave dicotómica ex tunc o ex nunc implica una visión sumamente reduccionista ${ }^{20}$ y hasta un tanto mítica ${ }^{21}$ del fenómeno jurídico. Con ello, indirectamente, se encubre el verdadero conflicto constitucional subyacente: que no es otro que la evidente tensión resultante de intentar equilibrar el respeto a la seguridad jurídica con los valores de igualdad y de justicia. ${ }^{22}$ No puede dejar de reconocerse que choca con un criterio mínimo de justicia dar por válidas y eficaces todas las relaciones jurídicas que nacieron y se desarrollaron bajo el amparo de la ley declarada inconstitucional, así como también que se vulneraría la necesaria seguridad jurídica que todo ordenamiento requiere cuando se acepta la absoluta ineficacia sobreviniente de todas las relaciones jurídicas antes indicadas.

No puede obviarse entonces que nos enfrentamos a un problema del derecho de carácter general, en el que "su solución no puede hacerse derivar como necesidad lógica de una determinada construcción dogmática ni expresarse mediante fórmulas sintéticas, como las que contraponen la eficacia ex nunc a la eficacia ex tunc o a la eficacia pro futuro. Es más bien un resultado impuesto por el derecho positivo". ${ }^{23}$

$\mathrm{Y}$ es justamente en la regulación jurídico-positiva donde el derecho comparado ha intentado resolver el problema o establecer pautas objetivas para su resolución. Por ello no resulta extraño que la mayoría de las leyes encargadas de regular a los tribunales constitucionales europeos, determinen que las sentencias estimatorias de inconstitucio-

${ }^{17}$ En profundidad sobre los orígenes de esta bipartición vid. Santamaría Pastor, Juan; "La nulidad de Pleno Derecho de los Actos Administrativos (contribución a una teoría de la ineficacia en el derecho público)", Instituto de Estudios Administrativos, Madrid, 1972, pp. 141 y ss.

18 Así Diez-Picazo; Luis, "La Derogación de las Leyes”, Civitas, Madrid, 1990, p. 265.

${ }^{19}$ En este sentido -e insinuando además la insostenibilidad de algunos fundamentos sobre la pretendida eficacia retroactiva de la nulidad-Santamaría Pastor, Juan, "Fundamentos de Derecho Administrativo I", Editorial Centro de Estudios Ramón Areces, Madrid, 1988, p. 422.

${ }^{20}$ Así Ipsen, Jörn; quien sugiere que la alternativa entre eficacia ex nunc y ex tunc carece de sentido si no se comparte la inconstitucionalidad como anulabilidad y el supuesto carácter constitutivo de la sentencia constitucional; Cfr. "Rechtsfolgen der Verfassungswidrigkeit von Norm und Einzelakt", Baden-Baden, 1980 , pp. 150 y ss.

${ }^{21}$ Así Jiménez Campo; Javier, ¿Qué Hacer con la Ley Inconstitucional?, en AA VV, "La Sentencia sobre la Constitucionalidad de la Ley", Tribunal Constitucional-Centro de Estudios Constitucionales, Madrid, 1997 , p. 42.

${ }^{22}$ En esta dirección Rubio Llorente, Francisco; La Jurisdicción Constitucional, en REDC N 22/1988, pp. 45-46; quien advierte además que ni siquiera la supuesta eficacia ex nunc que cabría atribuir a las sentencias de la Corte Constitucional italiana (en virtud de entender la inconstitucionalidad establecida en el art. 136 de la Constitución Italiana como anulabilidad) ha impedido anular sentencias penales dictadas en aplicación de leyes (posteriormente) inconstitucionales.

${ }^{23}$ Cfr. Rubio Llorente, p. 43. 
nalidad permitirán revisar procesos penales fenecidos, que han alcanzado la autoridad de cosa juzgada, en la medida en que beneficien o excluyan de pena al condenado. ${ }^{24}$

En Italia el art. 30.4 Ley $\mathrm{N}^{\circ} 87$ de 11 de Marzo de 1953 dispone que cuando en aplicación de la norma declarada inconstitucional ha sido pronunciada sentencia irrevocable de condena cesan la ejecución y todos los efectos penales. ${ }^{25}$

En Alemania la regla general es que las leyes declaradas inconstitucionales por el Tribunal Constitucional Federal $(B \operatorname{Verf} G)$ son nulas con efecto retroactivo $(\$ 24$ $\left.B \operatorname{Verf} G G^{26}\right)$, siendo incluso posible la revisión de los procesos penales ( $\$ 79 \mathrm{BVerfGG}$ ). Justamente debido a las duras consecuencias que se derivan de la nulidad, el $B \operatorname{Verf} G$ ha atemperado sus efectos mediante el desarrollo de una creativa jurisprudencia que con diversos criterios va acotando la drasticidad de la declaración de inconstitucionalidad (p/ej: la simple declaración de incompatibilidad de una norma inconstitucional, la declaración que no obstante la constitucionalidad de la ley el legislador puede adecuarla para lograr una plena constitucionalidad o evitar en el futuro una inconstitucionalidad y la interpretación conforme a la constitución). ${ }^{27}$

En España el art. 40.1 de la Ley Orgánica del Tribunal Constitucional establece la posibilidad de revisar procesos penales o contencioso-administrativos (referentes a un procedimiento sancionador) fenecidos y con fuerza de cosa juzgada a partir de la sentencia estimatoria de inconstitucionalidad de una ley (disposición o actos con fuerza de ley). Ello cuando, como consecuencia de la nulidad de la norma declarada inconstitucional, pueda resultar una reducción de la pena o sanción, o una exclusión, exención o limitación de responsabilidad (juzgamiento más favorable). ${ }^{28}$

En el ámbito de los sistemas latinoamericanos de jurisdicción constitucional el reconocimiento de la retroactividad - general o excepcional- de la sentencia de inconstitucionalidad también se encuentra consagrado.

En Colombia la sentencia de la Corte Constitucional C-113/93, al declarar inconstitucional el inc. $2^{\circ}$ del art. 21 del decreto $\mathrm{N}^{\circ} 2.067$ de 1991 (el cual autorizaba la retroactividad favorable de sus fallos en materia penal, policiva, disciplinaria y en relación al art. 149 de la Constitución), estableció que la determinación de los efectos en el tiempo de sus decisiones era de su propia competencia y no del legislador. ${ }^{29}$ Además conforme al art. 45 de la Ley $\mathrm{N}^{\circ} 270$ de 07/03/1996 (Estatutaria de la Administración

${ }^{24}$ Cfr. Blasco Soto, María del Carmen; "La Sentencia en la Cuestión de Inconstitucionalidad”, Bosch, Barcelona, 1995, p. 51.

${ }^{25}$ Cfr. Blasco Soto, op. y loc. cit.

${ }^{26}$ Ley reguladora del Tribunal Constitucional Federal.

${ }^{27}$ Häberle, Peter; El Recurso de Amparo en el Sistema Germano Federal, en V.V. A.A. (Coord: García Belaúnde y Fernández Segado), “La Jurisdicción Constitucional en Iberoamérica”, Dykinson, Madrid, 1997, pp. $270-271$.

${ }^{28}$ Vid. Almagro Nosete, op. cit., pp. 259-269.

${ }^{29}$ Brewer-Carías, Allan; La Jurisdicción Constitucional en América Latina, en V.V. A.A. (Coord: García Belaúnde y Fernández Segado), "La Jurisdicción Constitucional en Iberoamérica”, Dykinson, Madrid, 1997 , p. 157. 
de Justicia), la propia Corte Constitucional puede establecer, excepcionalmente, que sus resoluciones tengan efecto retroactivo. ${ }^{30}$

En Costa Rica, la Ley de Jurisdicción Constitucional establece, como principio general, que los efectos de la declaración de inconstitucionalidad son declarativos y retroactivos; salvo en lo referente a derechos adquiridos de buena fe (art. 91) o a situaciones consolidadas (por prescripción, caducidad o en virtud de una sentencia judicial). ${ }^{31}$

En México el art. 105 de la Constitución Política establece que la declaración de invalidez de las resoluciones dictadas por la Suprema Corte de Justicia de la Nación en relación a acciones de inconstitucionalidad que tengan por objeto plantear la posible contradicción entre una Ley y la Constitución no tendrá efectos retroactivos, salvo en materia penal, en la que regirán los principios generales y disposiciones legales aplicables de esta materia. El mismo enunciado es reiterado en el inc. $2^{\circ}$ del art. 45 de la ley reglamentaria respectiva. ${ }^{32}$

En el caso del Perú la regla general es que la sentencia del Tribunal Constitucional que declara inconstitucional una norma legal no tiene efecto retroactivo (art. 204 de la Constitución de 1993). Sin perjuicio de lo anterior el art. 83 del Código de Procedimiento Constitucional $^{33}$ (CPC) establece que las sentencias declaratorias de inconstitucionalidad permiten -en materia penal y tributaria- reabrir procesos concluidos (y con calidad de cosa juzgada) en los que se hayan aplicado las normas declaradas inconstitucionales. ${ }^{34}$ Esta situación no es nueva en el Perú y también -antes de la vigencia del CPC- el art. 40 de la Ley Orgánica Constitucional del Tribunal Constitucional facultaba excepcionalmente la aplicación retroactiva en materia penal y tributaria de los efectos derogatorios de una norma legal declarada inconstitucional por el mencionado tribunal, cuando de ello resultaba una situación más favorable (pudiéndose llegar incluso a afectar la cosa juzgada). ${ }^{35}$

Conforme a lo anterior, e independientemente de las fórmulas concretas que se utilicen, la mayoría de los sistemas de justicia constitucional -también el de los EE.UU._-36 reconocen dos principios: el de la inmutabilidad (inatacabilidad) de las sentencias firmes dictadas en aplicación de la ley declarada inconstitucional y el, "simétricamente inverso", de la nulidad de las sentencias condenatorias penales impuestas en virtud de la ley inconstitucional. Cuando se trata de leyes penales invariablemente se concede

${ }^{30}$ En el mismos sentido Nogueira Alcalá, La Sentencia Constitucional en Chile: Aspectos Fundamentales sobre su Fuerza Vinculante, ya cit., p. 102.

31 Cfr. Brewer-Carías, op. cit., p. 158.

${ }^{32}$ Ley Reglamentaria de las Fracciones I y II del artículo 105 de la Constitución Política de los Estados Unidos Mexicanos (publicada en el Diario Oficial de la Federación el 11 de mayo de 1995).

33 Para una revisión en profundidad de la importancia y alcances de este cuerpo legal que entró en vigencia a fines de 2004; vid. Eguiguren Praeli, Francisco; El Nuevo Código Procesal Constitucional Peruano, en Estudios Constitucionales No 1/2004, pp. 351-368.

${ }^{34}$ Cfr. Eguiguren Praeli; op. cit., p. 368.

${ }^{35}$ Cfr. Huerta Guerrero, Luis Alberto; El Proceso de Inconstitucionalidad en el Perú, en http://www.cajpe. org.pe/InformacionJuridica.htm

${ }^{36}$ Cfr. Rubio Llorente, op. cit., pp. 14-20. 
preferencia al valor de la justicia por sobre el principio de la seguridad jurídica (en España y Portugal el principio se extiende también a la nulidad de aquellas sentencias que han impuesto sanciones disciplinarias). ${ }^{37}$

\section{III. ¿QUÉ HA DE ENTENDERSE POR NO PRODUCIRÁ EFECTO RETROACTIVO?}

Pareciera que cualquier intento de solución al problema planteado inexorablemente no puede ser ajeno al derecho positivo. Y en este contexto la cláusula no producirá efecto retroactivo, establecida en el inciso segundo del art. 94 CPR, debe guiar todos los esfuerzos del intérprete con el fin de buscar alternativas hermenéuticas para su entendimiento que guarden correspondencia con los principios fundamentales sustentados por la propia constitución.

Ahora bien, la primera cuestión que debe determinarse es qué es lo que no produce efectos retroactivos (la sentencia, los efectos derogatorios o la publicación). Y en este sentido pareciera aparecer suficientemente claro -a partir de la construcción lógica y gramatical de la frase- que la cláusula en cuestión se encuentra referida a la sentencia estimatoria de inconstitucionalidad. En todo caso lo relevante de toda sentencia -también de ésta- es la decisión en ella contenida y, por consiguiente, lo que particularmente no producirá efecto retroactivo es la decisión misma de inconstitucionalidad sobre un determinado precepto legal.

Despejado lo anterior se hace necesario dilucidar a qué se refiere el constituyente cuando indica que la sentencia no producirá efecto retroactivo (irretroactividad). ¿Cuál es el efecto que expresamente le está negando el constituyente a la sentencia del TC? Naturalmente que las posibles respuestas son variadas, pero intentaremos condensarlas en tres categorías (excluyentes): irretroactividad máxima, irretroactividad media e irretroactividad minima.

\section{Irretroactividad máxima}

La primera alternativa interpretativa que surge es aquella planteada al inicio, cuando enunciamos el problema a ser abordado en este trabajo: los efectos derogatorios de la sentencia sobre el precepto legal declarado inconstitucional no podrían aplicarse a bechos

${ }^{37}$ Así categóricamente Rubio Llorente, op. cit., p. 46. Si estos principios han de extenderse a las leyes penales sustantivas exclusivamente o también a las procesales penales es una cuestión todavía abierta donde subsiste la discusión en torno a si, la declaración de inconstitucionalidad de una ley procesal, tendría también efecto retroactivo con carácter absoluto. Para el propio Rubio Llorente (cfr. op. cit., pp. 46-47) surgen divergencias en torno a la pacífica aceptación de éstos principios "en aquellos casos en los que la tensión entre los dos valores es de tal magnitud que hace difícil la aplicación pura y simple de los principios generales indicados, como sucede muy especialmente cuando la ley invalidada es una ley procesal penal. La eficacia ex tunc de la invalidación significa en este caso la anulación de todos los procesos en los que la ley fue utilizada y con ello probablemente la excarcelación de un buen número de delincuentes cuyas condenas, aunque irregulares según el nuevo standard, no fueron tal vez injustas". 
acaecidos con antelación a la publicación de la misma en el diario oficial, indistintamente que los mismos estuvieren aún pendientes de juzgamiento o que su juzgamiento bubiere adquirido ya la calidad de cosa juzgada.

Esta interpretación, que podríamos denominar irretroactividad máxima, resulta difícilmente sostenible; toda vez que en aquellos procesos recaídos sobre hechos anteriores a la sentencia del TC, pero que no se encuentran afinados, el juzgador se vería obligado a aplicar una norma desfavorable que - para todos los efectos- se encuentra derogada. Se trataría de un extrañísimo caso en el cual procedería considerar la ultractividad de un precepto legal en perjuicio del imputado (ultractividad im peius). La verdad es que no conocemos teoría de la ley penal alguna que pueda amparar ello. Cuando la ultractividad de una ley se admite es excepcionalmente y ello ocurre (descontando los discutidos supuestos de leyes temporales o excepcionales) sólo cuando la norma derogada es más favorable para el justiciable (ultractividad im melius), pero no a la inversa.

Una interpretación como ésta -en que los efectos derogatorios derivados de las sentencias estimatorias de inconstitucionalidad del TC no podrían retrotraerse a hechos acaecidos con anterioridad a la misma- nos lleva al absurdo jurídico de admitir que el juzgador se encontraría obligado a aplicar leyes derogadas y con ello determinado constitucionalmente a prevaricar en los términos del tipo previsto en el art. $223 \mathrm{~N}^{\circ} 1 \mathrm{CP}$.

Este absurdo ni siquiera tendría corrección a través de la jurisdicción constitucional; ya que el TC no podría decidir la inaplicabilidad (art. $93 \mathrm{~N}^{\circ} 6 \mathrm{CPR}$ ) para el juzgamiento pendiente de un precepto legal que se encuentra derogado (además por una decisión suya previa). En algunos sistemas de derecho comparado ${ }^{38}$ es dable la posibilidad de que una norma derogada propiamente tal (es decir, por una decisión legislativa), pero que sin embargo es aplicable ${ }^{39}$ pueda ser declarada inconstitucional. En términos generales, para aceptar dicha posibilidad, la declaración de inconstitucionalidad debe conllevar el cese absoluto de la aplicabilidad de la norma impugnada. ${ }^{40}$ De ahí entonces que en el sistema chileno no sea factible esta alternativa, pues el efecto derogatorio atribuido a la sentencia estimatoria sólo implica el cese prospectivo de su pertenencia al sistema jurídico.

${ }^{38}$ Por ejemplo en el sistema de jurisdicción constitucional peruano ello es posible, ya que la declaración de inconstitucionalidad anula la capacidad reguladora y los efectos de la norma impugnada. De este modo una vez declarada su inconstitucionalidad es imposible aplicarla. De ahí que sea jurídicamente factible, y además tenga un importante efecto práctico, la declaración de inconstitucionalidad de una ley derogada. Lo anterior ha sido confirmado por la jurisprudencia del propio Tribunal Constitucional; cfr. STC Peruano $\mathrm{N}^{\circ}$ 0019-2005-PI/TC de 21/07/2005.

${ }^{39}$ La aplicabilidad ultractiva de la norma legal derogada puede darse debido a situaciones ocurridas durante el tiempo de pertenencia de la norma al sistema jurídico o porque existe una norma que obliga a su aplicación (así p/ej. el art. 22 de la Ley de Efecto Retroactivo de las Leyes, que hace aplicable -sin perjuicio de algunas excepciones- las leyes que se encontraban vigentes al tiempo de celebración de todo contrato). Sobre la ultractividad de la ley derogada y su control de constitucionalidad, vid. Díez-Picazo; Luis, op. cit., pp. 220-232.

${ }^{40}$ Sobre esta interesante cuestión Cfr. Moreso Mateos; José Juan, Sobre Normas Inconstitucionales, en REDC No 38/1993, pp. 109-111. 
Por otro lado - con esta interpretación- se genera un problema de manifiesta desigualdad ante la ley entre el que delinque (o se le imputa un delito) antes del fallo del TC y el que lo hace (o se le imputa) después. En el primer caso habría sanción (o persecución) y en el segundo no habría o, bien, la sanción podría ser de un cuantum inferior. La desigualdad de desvaloraciones por parte del ordenamiento jurídico respecto de un mismo supuesto de hecho sería evidente y sin posibilidad de corrección. Ya vimos que esta desigualdad ni siquiera podía impugnarse a través de la inaplicabilidad, pero tampoco podría ésta normalizarse por el propio legislador ya que no es posible para éste derogar lo que ya fue expulsado y no pertenece al ordenamiento jurídico. ${ }^{41}$

\section{Irretroactividad media}

Otra alternativa interpretativa, que podríamos denominar irretroactividad media, sería sostener que el efecto retroactivo que se le niega a las sentencias del TC queda limitado sólo a la imposibilidad de afectar la cosa juzgada. Conforme a esta posición hermenéutica el efecto de irretroactividad impediría revisar únicamente aquellas sentencias judiciales que, habiendo hecho aplicación del precepto legal inconstitucional, se encontraren ejecutoriadas al momento del fallo del TC. Por su parte, en los procesos que se encontraren pendientes de juzgamiento al momento de la sentencia del TC, ésta sí poseería fuerza retroactiva y el consiguiente efecto derogatorio de la declaración de inconstitucionalidad podría extenderse a hechos pretéritos, pero aún no juzgados. ${ }^{42}$

Nótese que esta interpretación pareciera ser compartida por el mensaje del proyecto de ley (en actual tramitación) que modifica la Ley Orgánica Constitucional del Tribunal Constitucional chileno (LOCTC). Ya que -cuando se fundamenta específicamente lo relativo a los efectos de la sentencia de inconstitucionalidad (previstos en el artículo $47 \mathrm{~W}$ que se pretende introducir en la LOCTC)- se afirma que el "efecto

${ }^{41}$ Esta solución sólo sería posible en el caso de que nuestro TC tuviere la facultad de constatar únicamente -sin declarar necesariamente- la inconstitucionalidad y exhortar al legislador para que sea él quien corrija el déficit de constitucionalidad. Esta práctica es frecuentemente utilizada por el BVerfG Alemán; Cfr. Häberle, op. cit., p. 271.

42 Esta idea, en términos generales, fue sostenida por (Miguel) Otero Lathrop cuando concurrió -como profesor invitado- a la Comisión de Constitución, Legislación, Justicia y Reglamento del Senado (en el contexto de la discusión sobre las reformas constitucionales). Afirmando en dicha oportunidad "que para evitar el efecto retroactivo de la nulidad debe establecerse que la sentencia sólo producirá efectos para el futuro, después de publicada en el Diario Oficial. Con ello, las sentencias judiciales ejecutoriadas no serán afectadas y todo lo pendiente se resolverá con absoluta prescindencia de la norma declarada inconstitucional". Cfr. Informe del 18/03/2003 de la Comisión de Constitución, Legislación, Justicia y Reglamento del Senado, recaído en mociones de los HH. Senadores señores Chadwick, Díez, Larraín y Romero, y de los HH. Senadores señores Bitar, Hamilton, Silva y Viera-Gallo, con las que inician sendos proyectos que introducen diversas reformas a la Carta Fundamental (boletines $N^{o s}$ 2.526-07 y 2.534-07), p. 265. Coherente con su planteamiento Otero Lathrop propuso a la señalada Comisión incluir dentro de las normas constitucionales relativas al TC una del siguiente tenor: "Esta declaración no producirá efecto retroactivo alguno respecto de las sentencias que se encuentren ejecutoriadas a la fecha de su publicación ni de los derechos válidamente adquiridos durante su vigencia"; cfr., op. cit., p. 266. 
de la sentencia es que desde la fecha de su publicación, el precepto queda derogado; pero esa derogación no produce efecto retroactivo. Por ello, todas las situaciones nacidas y consolidadas con anterioridad, favorables o desfavorables, no son tocadas por la derogación ni permiten iniciar acciones de ningún tipo”. ${ }^{43}$ Al referirse sólo a las situaciones consolidadas pareciera que, en sentido contrario (y recurriendo a los mismos conceptos vagos que utiliza el mensaje), aquellas aún pendientes de consolidación sí podrían ser tocadas.

Una interpretación en esta dirección permitiría salvar parcialmente la eficacia del principio de retroactividad de la ley penal favorable; es decir, únicamente respecto de aquellos hechos cometidos bajo la vigencia del precepto inconstitucional y que no han alcanzado un juzgamiento en calidad de cosa juzgada al momento de la sentencia del TC. Pero aquellos procesos ejecutoriados en los que se ha hecho aplicación del precepto legal inconstitucional no podrían ser revisados y, extrañamente, el cambio favorable en las desvaloraciones del sistema del derecho no tendría impacto en la fase de ejecución de la sentencia; debiendo ésta cumplirse aunque la conducta que en ella se ha juzgado hubiere dejado de ser disvaliosa para el ordenamiento jurídico o lo sea en menor intensidad.

Es claro que este entendimiento de la cláusula conlleva un serio déficit de igualdad ante la ley. No es posible que para aquellos que hubieren obtenido una sentencia ejecutoriada antes del fallo del TC, el precepto legal que fundamenta la condena sea perfectamente compatible con la constitución, mientras que para el resto de los ciudadanos el mismo precepto legal resulte inconstitucional. Un tratamiento en este sentido implicaría el establecimiento de una diferencia de trato arbitraria - sin justificación racional- ${ }^{44}$ específicamente prohibida por la CPR (art. $19 \mathrm{~N}^{\mathrm{o}} 2$, inc. $2^{\circ}$ ).

Pero también afecta al principio de retroactividad de la ley penal favorable, el cual no reconoce límites temporales en la Constitución. Nótese que, justamente, por la inexistencia de dichos límites es que el art. 18 del Código Penal ha llevado el principio hasta el extremo de facultar la revisión de sentencias firmes incluso en los casos que ya se hubiere cumplido la condena (para evitar que perviva el efecto estigmatizante de la sanción penal). Si la propia Constitución -y también el Pacto Internacional de Derechos Civiles y Políticos (en adelante PIDCyP) y la Convención Interamericana de Derechos Humanos (en adelante $C A D H$ ) - han prescindido de limitar temporalmente la aplicación de este principio, estimamos entonces que le está vedado al intérprete la formulación de dichos límites. ${ }^{45}$

${ }^{43}$ Cfr. Mensaje del Presidente de la República No 432-353, de 07/12/2005 con el que inicia un Proyecto de Ley que Modifica la Ley No 17.997, Orgánica Constitucional del Tribunal Constitucional, p. 22.

${ }^{44}$ Vid. Nogueira Alcalá, Humberto, "El Derecho a la Igualdad en la Jurisprudencia Constitucional”, en Ius et Praxis $N^{\circ}$ 2, año 2, Universidad de Talca, Facultad de Ciencias Jurídicas y Sociales, Talca, Chile, 1997 , p. 237.

${ }^{45}$ Cfr. Instituto Interamericano de Derechos Humanos (Coord: Zaffaroni, Eugenio R.), "Sistemas Penales y Derechos Humanos en América Latina” (Informe final), Depalma, Buenos Aires, 1986, p. 13. 


\section{Nuestra posición: "no producirá efecto retroactivo" significa irretroactividad mínima}

Desde una perspectiva general retroactivo suele ser entendido como el adjetivo que recae sobre aquello "que obra o tiene fuerza sobre lo pasado" ${ }^{46}$. En el ámbito jurídico dicho entendimiento se concreta específicamente en la "traslación al pasado de los efectos de una ley, sentencia o acto jurídico" ${ }^{47}$. Pero la verdad es que por más que se la intente definir, con fórmulas más o menos acotadas, la retroactividad constituye un concepto jurídico indeterminado, al cual se le reconoce una compleja equivocidad que impide determinar con certeza los supuestos claramente subsumibles en su significado. ${ }^{48}$

Por eso es que ambas definiciones deben ser tomadas con reserva y no condicionar de manera mecánica nuestra búsqueda, ya que -en estricto rigor-el pasado siempre es irrevocable e irreversible en el tiempo con lo que mal podría modificarse por un acto posterior. Por eso no puede compartirse que el concepto de retroactividad exprese la eficacia y aplicación de una norma jurídica (cualquiera que fuese) a un momento anterior a su entrada en vigor. Es evidente - por un imperativo lógico- que la norma jurídica (también una sentencia) no puede ser aplicada en un tiempo anterior al de su propia existencia.

Lo que sí puede hacer la nueva norma (también una sentencia) -y en eso consiste precisamente la retroactividad- es recalificar o revalorar jurídicamente conforme a ella los hechos o relaciones jurídicas que hubieren surgido con antelación a su entrada en vigencia. Si se repara con atención en esta idea se observará que el efecto jurídico de la aplicación de la nueva norma siempre se producirá invariablemente en el presente (o futuro), pero con la peculiariedad de que podría estar referido además -si el derecho positivo lo permitiera- ${ }^{49}$ a la revaloración o recalificación de situaciones fácticas o jurídicas originadas en un tiempo anterior a su vigencia. ${ }^{50}$

Conforme a lo anterior la cláusula no producirá efecto retroactivo significa que la sentencia estimatoria de inconstitucionalidad no podrá revalorar o recalificar situaciones fácticas o jurídicas que hubiesen acaecido o nacido antes de que ella cobre eficacia. Le está vedado a la mencionada sentencia, por imperativo constitucional, extender su decisión (y sus efectos inherentes derogatorios) a hechos, relaciones jurídicas o procesos pretéritos, independientemente de que sean favorables o desfavorables o que se encuentren pendientes o fenecidos. La irretroactividad así entendida -y que podríamos denominar irretroactividad mínima-impide que la misma sentencia de inconstitucionalidad pudiere declarar inválidas relaciones jurídicas pretéritas sustentadas en el precepto legal decla-

\footnotetext{
${ }^{46}$ Cfr. R.A.E., "Diccionario de la Lengua Española”, T. II, $21^{a}$ ed., Madrid, 2001, p. 1967.

${ }^{47}$ Cfr. Capitant, Henri; "Vocabulario Jurídico”, Depalma, Buenos Aires, 1979, p. 492.

48 En este sentido Díez-Picazo; Luis, op. cit., pp. 209-210.

${ }^{49}$ Así en los sistemas de jurisdicción constitucional que han dispuesto expresamente la retroactividad (como el alemán) o también en aquellos (como el colombiano) que han delegado en el propio Juez de la Constitución la determinación de los efectos en el tiempo de su decisión.

${ }^{50}$ En el mismo sentido Blasco Soto, op. cit., pp. 30-31.
} 
rado inconstitucional o dejar sin efecto sentencias judiciales en que se hubiere hecho aplicación del referido precepto.

De este modo se convierte la irretroactividad mínima en una limitación que recae sobre el contenido decisorio-temporal de la propia sentencia estimatoria de inconstitucionalidad; no pudiendo ésta pronunciarse respecto a actos o relaciones jurídicas pretéritas, sin perjuicio de lo que atañe al precepto legal objeto de la litis constitucional que (obviamente) es un acto jurídico preexistente a la sentencia misma. Así la decisión de inconstitucionalidad se agota con la mera constatación/verificación de la contradicción axiológica existente entre el precepto legal y el ordenamiento constitucional. El efecto derogatorio sobre el precepto legal que se le atribuye a esta decisión de inconstitucionalidad (inc. $3^{\circ}$ del art. $94 \mathrm{CPR}$ ) no es una consecuencia jurídica inherente a la decisión, sino tan sólo la opción técnico-jurídica que el constituyente ha definido para reparar la inconstitucionalidad. ${ }^{51}$

Por eso, entonces, es posible sostener que cuando el constituyente afirma (en el art. 93 CPR) que la sentencia del TC no producirá efecto retroactivo está señalando un límite objetivo -que vincula sólo a dicha sentencia- con la finalidad de que la decisión de inconstitucionalidad no se extienda a hechos o relaciones jurídicas pasadas donde el precepto inconstitucional fue o pudiere ser aplicado. Indirectamente se busca impedir que la sentencia de inconstitucionalidad incurra en extra petita. Asimismo con dicha afirmación, de una u otra manera, se quiere establecer una presunción (iuris tantum) de validez respecto a las mencionadas relaciones jurídicas, pero que -debido a la concordancia que ha de existir entre los distintos preceptos constitucionales- no obsta a la revisión de las mismas por los Tribunales de Justicia conforme a otros mecanismos (distintos de la sentencia de inconstitucionalidad) o principios constitucionales, cuando éstos fueren procedentes.

Nótese que, por lo demás, la interpretación aquí defendida se muestra coherente con el sentido que se le asigna a la retroactividad en todos aquellos sistemas comparados de jurisdicción constitucional que le reconocen este efecto a la sentencia estimatoria de inconstitucionalidad (vid. supra III.-). Así, por ejemplo, el Tribunal Constitucional peruano visualiza en el art. 83 del CPC una directa y expresa autorización para que, en virtud de sus propias sentencias recaídas en procesos de inconstitucionalidad, se pueda declarar la nulidad de resoluciones judiciales amparadas en leyes penales declaradas inconstitucionales, cuando dicha retroactividad resulte más beneficiosa para el imputado. ${ }^{52}$

${ }^{51}$ Nótese que en otros sistemas de jurisdicción constitucional, como el español (art. 39.1 de la Ley Orgánica del Tribunal Constitucional) se ha optado por la nulidad como mecanismo reparatorio (eso sí la nulidad del sistema español no afecta los procesos fenecidos; salvo en materia sancionadora). Sobre la vinculación entre inconstitucionalidad y nulidad, así como sobre los efectos en el tiempo de esta última cfr. la STC (español) 49/1989 de 20/02/1989 (específicamente el fundamento de derecho $11^{\circ}$ ).

${ }^{52}$ Cfr. considerando $51^{\circ}$ de la STC peruano $N^{\circ} 0019-2005-\mathrm{PI} / \mathrm{TC}$ de 21/07/2005. 


\section{IV. ¿POR QUÉ NUESTRA POSICIÓN (IRRETROACTIVIDAd MÍNIMA) HABRÍA DE PREVALECER SOBRE LAS OTRAS?}

1. Porque es la que resulta más ajustada a la constitución entendida como una totalidad sistemática y armónica

1.1. Sobre la interpretación de la Constitución y el entendimiento del Derecho Procesal Constitucional

En un primer orden de ideas debemos aclarar dos cuestiones sumamente relevantes y que resultan previas en la argumentación en curso.

La primera es que la actividad interpretativa de la constitución representa una tarea por la cual se adscribe (o atribuye) el significado de los giros lingüísticos usados en el texto de la Constitución con el objeto de obtener una solución decisoria a problemas prácticos. ${ }^{53}$ Representa una específica actividad, dentro de la interpretación jurídica general, caracterizada básicamente por un objeto propio (la norma constitucional) que determina a su vez criterios o elementos hermenéuticos particulares ${ }^{54}$ (complementarios del tradicional). La trascendencia de esta clase de interpretación radica en que sin ella no es posible descifrar el contenido concreto de una Constitución y, por lo mismo, su ausencia repercute en una incompleta teoría de la Constitución y del Derecho Constitucional. ${ }^{55}$

La segunda de las cuestiones radica en clarificar que no compartimos la tesis, por algunos planteada, ${ }^{56}$ de que nos situamos frente a un problema general de naturaleza procesal (vid. supra nota a pie $N^{o} 14$ ). Estimamos que la interpretación de los conceptos e instituciones procesales con relevancia constitucional debe hacerse -siempre y en todo caso- en clave constitucional material. Por ello, en este orden de ideas, resulta acertado sostener que el Derecho Procesal Constitucional es, antes que Derecho Procesal, un Derecho Constitucional concretizado (Kokretisiertes Verfassungsrecht). ${ }^{57} \mathrm{La}$ consecuencia inescindible de una tal posición es que el Derecho Procesal Constitucional debe ser extraído materialmente del Derecho Constitucional e interpretado conforme a éste.

\footnotetext{
53 En este sentido Gómes Canotilho; "Direito Constitucional”, 6a ed., Ed. Almedina, Coimbra, 1993, p. 202.

${ }^{54}$ Vid. Díaz Revorio, "Valores Superiores e Interpretación Constitucional”, Centro de Estudios Políticos y Constitucionales, Madrid, 1997, p. 40.

55 En sentido similar Requena López; "Sobre la Función, los Medios y los Límites de la Interpretación de la Constitución”, Comares, Granada, 2001, pp. 25-27.

${ }^{56}$ En este sentido Blasco Soto; op. cit. p. 46.

${ }^{57}$ Cfr. en este sentido Häberle, Peter; Grundprobleme der Verfassungsgerichtsbarkeit, en AA. VV. (Coord: el mismo) "Verfassungsgerichtsbarkeit", Darmstadt, 1976, p. 23.
} 


\subsection{La debilidad del elemento histórico para articular una interpretación} constitucional

Estimamos que ha de restársele valor a aquellas interpretaciones que pudieren surgir a partir de la mera consideración del elemento histórico, como ocurre con la intención declarada en el mensaje del proyecto de ley -en actual tramitación- que modifica la ley Orgánica Constitucional del Tribunal Constitucional. ${ }^{58}$

Aunque aparezca clara cuál es la intención del legislador, ella no puede extrapolarse al contenido de la norma constitucional. Es comúnmente aceptado en la doctrina constitucional $^{59}$ que de las cuatro reglas generales de interpretación jurídica enunciadas por von Savigny -gramatical, sistemática, teleológica e histórica- la única que no puede servir de base y poseer la suficiencia para, por sí sola, estructurar una interpretación es la última de las nombradas. Su utilización podría aceptarse de modo complementario y en la medida de que guarde correspondencia con las otras reglas propias de la hermenéutica constitucional (y también generales). La razón de su debilidad es clara: "la interpretación es interpretación de normas, desvinculadas de la motivación o intención política del legislador al dictarlas". ${ }^{60}$

\subsection{La necesidad de resguardar el principio de concordancia práctica}

Desde nuestra posición interpretativa (irretroactividad mínima) no aparece necesario sacrificar norma constitucional alguna. Ella es la única de las interpretaciones barajadas que se muestra compatible con la incolumidad de aquellas otras normas constitucionales (art. 19. $\mathrm{N}^{\mathrm{o}} 3$, inc. $7^{\circ}$ y art. $19 \mathrm{~N}^{\circ} 2$, inc. $2^{\circ}$ ) involucradas en el problema planteado.

Ya vimos que de sostenerse la irretroactividad máxima el juzgador tendría que aplicar en todos los casos normas derogadas en perjuicio del imputado (ultractividad im peius). Y con ello el derecho a la retroactividad de la ley penal más favorable aparecería vulnerado por una disposición constitucional (art. 94, inc. $2^{\circ}$ CPR). Por su parte, de admitirse la irretroactividad media, no se podrían revisar las condenas penales (ejecutadas o en ejecución) impuestas por sentencia ejecutoriada y sustentadas en ley declarada inconstitucional, sin perjuicio de que ésta última no sería aplicable a los procesos pendientes. De este modo los derechos constitucionales relativos a la retroactividad de ley penal favorable (art. 19. $\mathrm{N}^{\mathrm{o}} 3$, inc. $7^{\circ} \mathrm{CPR}$ ) y a la prohibición de establecer diferencias arbitrarias (art. 19. No 2 , inc. 2 CPR) aparecerían vulnerados ambos por una disposición constitucional (art. 94, inc. $\left.2^{\circ} \mathrm{CPR}\right)$.

Pero una contradicción así, al interior de la Constitución, no puede ser aceptada. El principio de unidad de la Constitución y el de su concordancia práctica, obligan a

\footnotetext{
58 Vid. Mensaje del Presidente de la República No 432-353, de 07/12/2005 con el que inicia un Proyecto de Ley que Modifica la Ley No 17.997, Orgánica Constitucional del Tribunal Constitucional, p. 22.

${ }^{59}$ Vid. por todos Pérez Royo, Javier, "Curso de Derecho Constitucional”, 10a ed., Marcial Pons, Madrid/Barcelona, 2005, pp. 138-139.

${ }^{60}$ Cfr. Pérez Royo, Javier, op. cit., p. 139.
} 
considerar las distintas disposiciones constitucionales como un complejo normativo coherente y armónico. ${ }^{61}$ De ahí que todo aparente conflicto entre ellas ha de ser resuelto ponderando los valores de mayor relevancia con sus límites respectivos a partir de una consideración unitaria del sistema.

Tanto la perspectiva de la irretroactividad máxima como de la irretroactividad media privilegian e imponen en sus consecuencias el valor de la seguridad jurídica por sobre el goce de derechos constitucionales fundamentales. Un tal proceder no es constitucionalmente tolerable. El principio de la retroactividad de la ley penal favorable (art. 19. $\mathrm{N}^{\circ} 3$, inc. $7^{\circ}$ ), así como el de igualdad ante la ley (art. $19 \mathrm{~N}^{\circ} 2$, inc. $2^{\circ}$ ) son garantías o derechos establecidos en favor del ciudadano para defenderse frente a la autoridad y, por eso, no pueden ser recortados o disminuidos sino en los casos a que específicamente se refiere la propia norma constitucional. Incluso cuando se autoriza su limitación, ésta no puede llegar a afectar la esencia del derecho (cuestión que además constituye autónomamente un derecho asegurado por la Constitución; art. 19 N $^{\circ} 26$ CPR). En este orden de ideas no parece razonable ni proporcionado limitarlos mediante una interpretación que le pretende otorgar a la seguridad jurídica una valoración preponderante. Desde la propia perspectiva del bloque constitucional de derechos fundamentales asegurados por la Constitución queda claro que, en una eventual tensión, la seguridad jurídica habría de ceder inevitablemente frente a la relevancia axiológica de dicho bloque.

En todo caso obsérvese que la configuración del principio de legalidad penal y su consiguiente característica general de irretroactividad, en esencia, pretende también seguridad jurídica. Busca proteger al ciudadano respecto del ejercicio sorpresivo del ius puniendi. Esta función de la seguridad jurídica -inherente a la prohibición de retroactividad de las normas penales- pierde su razón de ser cuando se quiere impedir que se sigan restringiendo los derechos fundamentales de los ciudadanos en los casos en que el ordenamiento jurídico-penal ya no lo considera necesario, o que subsistan sanciones cuya gravedad ha sido cuantitativa o cualitativamente disminuida. ${ }^{62}$ De esta manera el principio de retroactividad favorable no alcanza a entrar en pugna con la seguridad jurídica; porque en los casos a los cuales se aplica la retroactividad (favorable) la seguridad jurídica ha dejado de ser necesaria, carece de finalidad protectora.

Por otro lado es cierto que se podría argumentar que el derecho a la retroactividad de la ley penal favorable sólo sería aplicable ("a menos que una nueva ley favorezca al afectado”) a los casos en que existe una nueva ley propiamente tal (en el sentido técnico formal de norma jurídica originada en la potestad legislativa) y no cuando una sentencia constitucional ha modificado el ordenamiento jurídico. Además el art. $18 \mathrm{CP}$, cuando regula el ejercicio de este derecho, hace alusión a que la ley favorable debe haber sido

${ }^{61}$ Con estos principios -según Pérez Royo; Javier (cfr. op. cit., p. 144)- se busca optimizar las normas constitucionales entre las que puede darse una especie de tensión en la práctica. De ahí que la Constitución deba ser interpretada con la finalidad de evitar que se produzca el sacrificio de una norma o valor constitucional en aras de otra norma o valor.

${ }^{62}$ En este sentido Huerta Tocildo; op. cit., pp. 97-98. 
promulgada ("se promulgare otra ley" y "Si la ley que exima el hecho de toda pena o le aplique una menos rigurosa se promulgare después de ejecutoriada la sentencia”).

Pero desde nuestra perspectiva un tal argumento ha de ser rechazado por superficial, literalista y afectar en su esencia al derecho en cuestión (art. 19 No 26 CPR). Responde a una idea vetusta de que el ordenamiento jurídico sólo podía ser modificado por leyes en sentido estricto. Es indudable que el trámite de promulgación no existe en la sentencia de inconstitucionalidad, pero ello no puede ser un argumento válido para restringir el ejercicio de un derecho fundamental; que por lo demás, en el reconocimiento que le dispensa el Derecho Internacional de los Derechos Humanos, no conoce esta vinculación al acto promulgatorio. Tanto el PIDCyP (art. 15.1) como la $C A D H$ (art. 9) se refieren únicamente a la "ley" cuando consagran este derecho. ${ }^{63}$

Así como es evidente que la sentencia de inconstitucionalidad no es una ley en sentido técnico formal, resulta innegable que ella constituye una fuente del derecho con plena legitimidad constitucional para modificar el sistema de normas. Por ello posee eficacia para -a través de su efecto derogatorio- eliminar la pertenencia al ordenamiento jurídico y la cesación de la vigencia de aquellos preceptos legales declarados inconstitucionales. En el sistema chileno cuando el TC declara la inconstitucionalidad de un precepto legal que contiene una determinada materia penalmente prohibida, dicha decisión es idéntica -en sus efectos materiales- a la derogación que pudiere hacer el legislador respecto del mismo precepto legal. Esta identidad sustancial que apuntamos también se presenta de modo general en todos aquellos ordenamientos (inspirados en directrices Kelsenianas) en los cuales para preservar la seguridad jurídica se limitan los efectos de la declaración de inconstitucionalidad sólo hacia el futuro. ${ }^{64}$

Si no existe diferencia sustancial entre el efecto derogatorio de la sentencia de inconstitucionalidad y la derogación derivada de un acto legislativo ${ }^{65}$ es jurídicamente posible entender que el principio de retroactividad de la ley penal favorable también se extiende a los supuestos en que el ordenamiento jurídico es modificado mediante una fuente del derecho formalmente diversa a la ley, pero de idénticos efectos materiales. Situación que, por lo demás, es constitucionalmente aceptable porque el principio de legalidad penal no impide, de modo absoluto, considerar fuentes diversas a la ley cuando éstas benefician al justiciable con una menor punibilidad o bien con su ausencia. ${ }^{66}$ Las limitaciones que surgen a partir de la fundamentación democrático representativa del principio de legalidad consistentes en que sólo el poder legislativo es el único que, como representante de la voluntad popular, puede crear delitos y establecer penas dejan de tener sentido y se flexibilizan cuando otras fuentes ${ }^{67}$ pasan a conformar el ordenamiento jurídico y -de

\footnotetext{
${ }^{63}$ Ambos instrumentos internacionales utilizan -en los artículos citados- idéntica redacción para configurar el derecho en cuestión: "Si con posterioridad a la comisión del delito la Ley dispone la imposición de una pena más leve, el delincuente se beneficiará de ello”.

${ }^{64}$ Cfr. Díez-Picazo; op. cit., pp. 261-262.

65 Así Díez Picazo, op. cit., p. 261.

66 Vid., por todos, Jeschek/Weigend, op. cit., pp. 119-120 y 143.

${ }^{67}$ Obsérvese que incluso, en los supuestos de retroactividad favorable, estas otras fuentes podrían ser de menor jerarquía normativa que la ley. Así la costumbre en el caso del art. 54 de la ley $\mathrm{N}^{\circ} 19.253$, o
} 
su integración con éste- se derivan consecuencias jurídico-penales más beneficiosas (ya sea en relación al injusto, a la responsabilidad penal o a la pena). ${ }^{68}$

Conviene advertir que este entendimiento de "ley" sólo es posible asumirlo en el sentido que hemos señalado unidireccionalmente; no pudiendo predicarse respecto de la "ley" como fuente creadora de delitos y penas, la que deberá ser siempre -y en todo caso- una ley en los términos del art. 63 CPR. El entendimiento señalado en caso alguno es contradictorio y resulta plenamente coherente con la función que, por un lado, posee la ley como límite restrictivo de derechos fundamentales (ley formal) y, por otro, con el sentido que de ella pudiere hacerse en cuanto conjunto de normas que reconocen y garantizan el ejercicio y goce de los mismos derechos (ordenamiento jurídico). Por lo demás en esta misma perspectiva se ha pronunciado la Corte Interamericana de Derechos Humanos $(C I D H)$ en relación al alcance que debe dársele a la expresión ley usada en algunas disposiciones del texto de la $C A D H .{ }^{69}$

Lo relevante entonces para la operatividad del principio de retroactividad en cuestión es que se alteren favorablemente -en el ordenamiento jurídico- los presupuestos sobre los que descansa la aplicación de una consecuencia jurídico-penal. ${ }^{70}$ Así el término "nueva ley" usado por el constituyente en el art. $19 \mathrm{~N}^{\mathrm{o}} 3$, inc. $7^{\circ}$ ("a menos que una nueva ley favorezca al afectado") debe ser entendido como nueva conformación del ordenamiento jurídico. ${ }^{71}$ Si esta nueva conformación del ordenamiento jurídico conlleva un más favorable estándar de valoración/desvaloración del hecho sometido a juzgamiento la obligación del juez ordinario, de juzgar conforme a la ley, no puede significar -en el Estado de

bien un reglamento, cuando éste integra el tipo legal mediante un reenvío constitucionalmente compatible (p/ej art. $314 \mathrm{CP}$ ). En relación a la admisibilidad de la aplicación retroactiva favorable de un reglamento cfr. De Luca; Javier Augusto, "Leyes Penales más Benignas, en Blanco y Constitución Nacional”, Ad hoc, Buenos Aires, 1997, pp. 81-83 y Carbonel Mateu; Juan Carlos, "Derecho Penal: Concepto y Principios Constitucionales”, $2^{a}$ edición, Tirant Lo Blanch, Valencia, 1996, p. 142.

${ }^{68}$ Vid. Bacigalupo Zapater; Enrique, "Principios Constitucionales de Derecho Penal", Ed. Hammurabi, Buenos Aires, 1999, pp. 51-53.

${ }^{69}$ Cfr. la Opinión Consultiva (OC) 7/86 del 29/08/1986 serie A, núm. 7 referida (entre otras materias) al alcance de la expresión ley en el art. 14.1 (relativo a la configuración del derecho de rectificación o respuesta) de la $C A D H$. Aunque no conocemos pronunciamiento específico de la $\mathrm{CIDH}$ sobre el alcance de la expresión ley en el art. 9 de la $\mathrm{CADH}$; resulta relevante para nuestra argumentación la OC 6/86 del 09/05/1986, serie A, núm. 6, párrafo 11. En esta última la Corte precisa que el vocablo ley no ha sido necesariamente utilizado a lo largo de la Convención para expresar un concepto unívoco y que, por tanto, su significado debe determinarse y definirse específicamente en cada caso, recurriéndose para ese efecto a las correspondientes normas de derecho internacional aplicables a la interpretación de los tratados.

70 Así Carbonel Mateu, op. cit., pp. 141-142.

${ }^{71}$ A su vez el ordenamiento jurídico no debe acotarse, tan sólo, al conjunto de normas (que han sido positiva y válidamente creadas) existentes en ese momento, sino que ha de ser comprendido "como el conjunto de normas que, de una u otra manera, configuran las situaciones y relaciones jurídicas en dicho momento relevantes"; cfr. Díez-Picazo; Luis, op. cit., p. 233. Por otro lado obsérvese que el constituyente chileno en distintos lugares de la Constitución ocupa el término ley para referirse al conjunto del ordenamiento jurídico (así en el art. $7^{\circ} \mathrm{CPR}$ cuando establece que los órganos del Estado actúan válidamente previa investidura regular de sus integrantes, dentro de su competencia y en la forma que prescriba la "ley"). 
Derecho- únicamente la aplicación de la ley en sentido técnico, sino que ante todo equivale a la sumisión del juez al conjunto del ordenamiento jurídico. ${ }^{72}$

De este modo si no existe problema jurídico alguno en equiparar los efectos derogatorios de una ley sobre un precepto penal desfavorable con los efectos derogatorios de la sentencia estimatoria de inconstitucionalidad sobre el mismo precepto legal, la aplicación del principio constitucional de retroactividad de la ley penal favorable (art. 19. $\mathrm{N}^{\circ} 3$, inc. $7^{\circ} \mathrm{CPR}$ ) también se convierte en un imperativo constitucional en relación a los efectos derogatorios de la sentencia estimatoria de la inconstitucionalidad de un precepto legal (penalmente desfavorable).

Por lo tanto la irretroactividad mínima aparece como la única de las interpretaciones con capacidad de evitar la tensión entre seguridad jurídica y los principios aludidos. Su correspondencia con el sistema de nuestra Constitución, entendida como un todo armónico, constituye el fundamento preponderante de su validez.

\section{Permite solucionar problemas diversos al de la retroactividad de la ley penal favorable}

La interpretación que hemos propuesto no sólo permite salvar satisfactoriamente la vigencia del principio de retroactividad de la ley penal favorable, sino que también posee la versatilidad necesaria para posibilitar soluciones a los problemas de intertemporalidad que pudieren presentarse en otros ámbitos del ordenamiento jurídico. Al entenderse la irretroactividad sólo como una limitación que afecta únicamente a la propia sentencia de inconstitucionalidad (irretroactividad mínima), desaparece el impedimento constitucional para que pudieren revisarse, conforme a los principios generales del derecho (buena/mala fe, responsabilidad del Estado legislador, etc...), aquellas situaciones jurídicas perjudiciales derivadas de la aplicación del precepto legal inconstitucional. En este sentido se ha planteado que la irretroactividad de la sentencia de inconstitucionalidad debe ser entendida para los efectos de no lesionar derechos adquiridos de buena fe, porque de lo contrario implicaría una forma de sanear los perjuicios ocasionados por el propio legislador y una clara contravención de las bases de la institucionalidad (arts. $1^{\circ}$, inc. $4^{\circ}$ y $5^{\circ}$, inc $2^{\circ}$ de la CPR) y de algunas garantías constitucionales (como el art. $19 \mathrm{~N}^{\mathrm{o}} 24 \mathrm{CPR}$ ). ${ }^{73}$

\section{SUPUESTOS PROBLEMÁticos RELACIONADOS}

\section{La sentencia desestimatoria que declara incompatible con la Constitución una determinada interpretación del enunciado legal}

Un problema relacionado con el que hemos estado abordando es aquel derivado de los efectos que pudieren tener aquellas sentencias que, si bien desestiman la inconstitu-

72 Así De Otto; Ignacio, "Estudios sobre el Poder Judicial”, Ministerio de Justicia (Secretaría Gral. Técnica), Madrid, 1989, p. 67 y también, en sentido similar, Carrillo; Marc, La Aplicación Judicial de la Constitución, en REDC No 71-2004, p. 75.

${ }^{73}$ Vid. Fernández González; op. cit., pp. 143-145. 
cionalidad de un precepto, excluyen una o más interpretaciones posibles del enunciado legal por ser incompatibles con la Constitución. Se trata de supuestos en que la sentencia es desestimatoria de la pretensión de inconstitucionalidad, pero le resta valor a una específica interpretación del mismo. ${ }^{74}$

No es posible extrapolar para estos supuestos las consecuencias derivadas de una interpretación como la que hemos propuesto (irretroactividad mínima). En primer lugar porque no estamos frente a una nueva conformación del ordenamiento jurídico, sino tan sólo frente a una nueva forma de ser éste entendido, en la que sólo se produce una relectura de la voluntad legislativa preexistente. ${ }^{75}$ Obsérvese que ni siquiera acogiendo una tesis como la propuesta por Jiménez Campos ${ }^{76}$-en orden a que toda sentencia interpretativa tiene siempre un alcance materialmente estimatorio (ya que, directa o indirectamente niegan la constitucionalidad de una norma deducible del enunciado legal) - se podría llegar a sostener una nueva conformación del ordenamiento jurídico; toda vez que el enunciado legal no ha sido alterado y por lo tanto pervive. Y en segundo lugar porque, conforme al diseño constitucional chileno, no puede haber efecto derogatorio del precepto legal sin decisión estimatoria de inconstitucionalidad.

En todo caso, respecto de los juzgamientos pendientes, la nueva interpretación podrá ser siempre invocada; toda vez que ello se producirá en el contexto del proceso general de integración jurídica que desarrolla el juzgador al momento de aplicar la ley penal al caso concreto.

Ahora bien, invocar la nueva interpretación es inviable en el caso de sentencias ejecutoriadas que han establecido penas a partir de la interpretación declarada inconstitucional. Sin embargo, es evidente que pugna con las más elementales razones de justicia el continuar afectando los derechos de un sujeto, cuando aquella interpretación de la norma legal que opera como presupuesto de la sanción penal ya no es aceptada por ser contraria a la Constitución. ${ }^{77}$

Por eso -en el caso de sentencias ejecutoriadas- la única posibilidad para remediar esta injusta situación sería considerar la nueva interpretación del TC como un hecho nuevo y con ello fundamentar una revisión penal (art. 473 letra d del Código Procesal Penal y art. 657 No 4 del Código de Procedimiento Penal). ${ }^{78}$

${ }^{74}$ En Chile no existe -ni en la CPR ni en la LOCTC-obligación de publicar en el Diario Oficial esta clase de sentencias, con lo que el desconocimiento de cuál es la interpretación ajustada a la Constitución (y cuál la contraria) se puede llegar a tornar en generalizado y, con ello, presentar un serio problema de inseguridad jurídica y de desigualdad ante la ley.

75 Vid. Schüneman; Bernd, "Nulla Poena Sine Lege?", Walter de Gruyter, Berlin/New York, 1978, pp. 27-29.

${ }^{76}$ Cfr. op. cit., p. 45.

77 Cfr. en este sentido Vidales Rodríguez; Caty, "La Eficacia Retroactiva de los Cambios Jurisprudenciales”, Tirant Lo Banch, Valencia, 2001, pp. 212-214.

${ }^{78}$ Sobre esta solución propuesta resulta ilustrativo hacer presente que el Tribunal Constitucional español ha establecido que la declaración contenida en la ratio decidendi de una sentencia suya puede llegar a constituir un hecho nuevo para los efectos de la revisión penal; cfr. la STC 150/1997 de 29/09/1997 (específicamente el fundamento de derecho $3^{\circ}$ ). Además la causal de la revisión penal consistente en nuevos 


\section{La declaración de inconstitucionalidad de una ley penal favorable}

Hasta aquí hemos abordado el análisis suponiendo que el precepto legal declarado inconstitucional por el TC es desfavorable para el imputado, pero es posible imaginar también supuestos en que el precepto legal cuya constitucionalidad se objeta resulte más favorable al imputado.

Esta hipótesis se presentaría, por ejemplo, si se declarara la inconstitucionalidad de un tipo privilegiado como el infanticidio (art. 394 CP); el cual se entendería derogado desde la publicación de la sentencia del TC en el diario oficial y desde dicho momento los supuestos fácticos a los cuales estaba referido el tipo privilegiado pasarían a ser abarcados por el tipo base (parricidio, art. 390 CP).

En el caso de las sentencias ejecutoriadas pareciera no haber duda respecto a su intangibilidad, toda vez que la ley posterior no es más favorable y por lo tanto es inexistente el presupuesto constitucional y legal que autoriza la revisión de una sentencia que posee autoridad de cosa juzgada.

El problema se podría presentar en torno a aquellas situaciones pendientes de enjuiciamiento. Pero, conforme al principio de retroactividad de la ley penal favorable, si la ley posterior no beneficia (es desfavorable) no puede ser aplicada (art. $19 \mathrm{~N}^{\circ} 3$, inc. $\left.7^{\circ} \mathrm{CPR}\right) \mathrm{y}$, en este caso, el juzgador tendría que aplicar la ley vigente al momento del hecho. La circunstancia de encontrarse esta ley derogada al momento de su aplicación por el juzgador en nada afecta a la solución propuesta; ${ }^{79}$ ya que la aceptación de la ultractividad en favor del imputado (ultractividad im melius) es una de las consecuencias inherentes al principio de legalidad penal. ${ }^{80}$ Debemos hacer presente eso sí que esta solución -posible en el derecho chileno- no tiene cabida en aquellos sistemas de jurisdicción constitucional en que la decisión de inconstitucionalidad sobre la norma jurídica determina, no sólo el cese de su pertenencia al ordenamiento jurídico (derogación), sino que también el cese de su aplicabilidad (invalidez). ${ }^{81}$

\section{CONCLUSIONES}

1.- El efecto de la declaración de inconstitucionalidad sobre un precepto legal que realiza el TC es su derogación; es decir, produce el cese de su pertenencia al ordenamiento

\footnotetext{
bechos contemplada en el artículo 954.4 de la Ley de Enjuiciamiento Criminal está redactada en los mismos términos a la prevista en nuestra legislación procesal penal.

${ }^{79}$ En este sentido la Corte Suprema -en la sentencia de 17/06/1991- ha reconocido expresamente como jurídicamente posible la aplicación de una ley penal derogada; cfr. dicha sentencia en Fallos del Mes No 391/1991, pp. 219 y ss. Vid. también sobre esta cuestión Bascuñán Rodríguez; Antonio, La Aplicación de la Ley Penal Derogada, en Revista del Abogado N 17/1999.

${ }^{80}$ Así Ferrajoli; Luigi, op. cit., pp. 381-382 y 705.

${ }^{81}$ Cfr. en este sentido los considerando 61 y ss. de la STC peruano No 0019-2005-PI/TC de 21/07/2005. En la referida resolución se establece que debe dejar de aplicarse una ley penal favorable (en aquellos procesos que se encuentran pendientes al momento de declararse su inconstitucionalidad).
} 
jurídico. El mencionado efecto se deriva de la propia regulación constitucional y no de categorías apriorísticas sobre la naturaleza jurídica de dicha declaración.

2.- Cuando la Constitución establece que la sentencia de inconstitucionalidad no tendrá efecto retroactivo, quiere decir que la misma no puede pronunciarse sobre la eficacia o ineficacia de las relaciones jurídicas pretéritas sustentadas en el precepto legal declarado inconstitucional o dejar sin efecto sentencias judiciales en que se hubiere hecho aplicación del referido precepto (irretroactividad mínima).

3.- La retroactividad de la ley penal favorable es un principio general del derecho penal integrante del bloque constitucional de derechos fundamentales. Su eficacia no sólo se agota en el cambio favorable que se pudiere derivar de una ley, en sentido técnico formal, sino que se extiende también a las valoraciones favorables que pudieren surgir en el ordenamiento jurídico cuando tuvieren su origen en una sentencia (del TC) estimatoria de inconstitucionalidad.

4.- Lo concluido en VI.2. no impide que -en estricta observancia del principio constitucional de retroactividad de la ley penal favorable - los Tribunales de Justicia, cuando juzguen hechos con relevancia jurídico-penal acaecidos antes de la sentencia estimatoria de inconstitucionalidad, lo hagan con prescindencia del precepto legal declarado inconstitucional.

5.- La conclusión contenida en VI.2.- no afecta la competencia que el art. 18 CP le entrega a los Tribunales de Justicia en orden a modificar (de oficio o a petición de parte) aquellas sentencias ejecutoriadas en que se deba aplicar el principio constitucional de retroactividad de la ley penal favorable.

\section{BIBLIOGRAFÍA}

Almagro Nosete, José, Justicia Constitucional, 2a ed., Tirant Lo Blanch, Valencia, 1989.

Bacigalupo Zapater, Enrique, Principios Constitucionales de Derecho Penal, Ed. Hammurabi, Buenos Aires, 1999.

Bascuñán Rodríguez, Antonio, "La Aplicación de la Ley Penal Derogada", en Revista del Abogado $\mathrm{N}^{\circ} 17 / 1999$.

Blasco Soto, María del Carmen, La Sentencia en la Cuestión de Inconstitucionalidad, Bosch, Barcelona, 1995.

Bocanegra Sierra, Raúl, El Valor de las Sentencias del Tribunal Constitucional, Instituto de Estudios de Administración Local, Madrid, 1982.

Boix ReIg, Javier, "El Principio de Legalidad en la Constitución”, en AA. VV., Repercusiones de la Constitución en el Derecho Penal, Publicaciones de la Universidad de Deusto, Bilbao, 1983.

Brewer-Carías, Allan, "La Jurisdicción Constitucional en América Latina", en V.V. A.A. (Coord: García Belaunde y Fernández Segado), La Jurisdicción Constitucional en Iberoamérica, Dykinson, Madrid, 1997, p. 121-161. 
Capitant, Henri, Vocabulario Jurídico, Depalma, Buenos Aires, 1979

Carbonel Mateu, Juan Carlos, Derecho Penal: Concepto y Principios Constitucionales, $2^{\mathrm{a}}$ edición, Tirant Lo Blanch, Valencia, 1996.

Carrillo, Marc, "La Aplicación Judicial de la Constitución”, en Revista Española de Derecho Constitucional No 71-2004, p. 75.

Cea Egaña, José Luis, "Imagen del Juez y de la Justicia Constitucional en América Latina”, ponencia a la V Conferencia Iberoamericana de Justicia Constitucional, 21/08/2006, en http://www.tribunalconstitucional.cl/site/documentos/documentos.html

De Luca, Javier Augusto, Leyes Penales más Benignas, en Blanco y Constitución Nacional, Ad hoc, Buenos Aires, 1997.

De Otto, Ignacio, Estudios sobre el Poder Judicial, Ministerio de Justicia (Secretaría Gral. Técnica), Madrid, 1989.

Díaz Revorio, Valores Superiores e Interpretación Constitucional, Centro de Estudios Políticos y Constitucionales, Madrid, 1997.

Díez-Picazo, Luis, La Derogación de las Leyes, Civitas, Madrid, 1990, p. 265.

Eguiguren Praeli, Francisco, "El Nuevo Código Procesal Constitucional Peruano", en Estudios Constitucionales $\mathrm{N}^{\circ} 1 / 2004$, pp. 351-368.

Eser, AlbIn, “Comentarios a los $§ § 1$ y 2”, en Schönke-Schröder, Strafgesetzbuch Kommentar (25 ed.) Beck, Munich, 1997, pp. 49-61.

Fernández González, Miguel Angel, "La Sentencia del Tribunal Constitucional, su Eventual Carácter Vinculante y la Inserción en las Fuentes del Derecho", en Estudios Constitucionales $\mathrm{N}^{\circ} 1 / 2006$, pp. 125-149.

Ferrajoli, Luigi, Derecho y Razón (Teoría del Garantismo Penal), Trotta, Madrid, 1995.

Frígols i Brines, Eliseu, El Principio de Irretroactividad y la Sucesión de Leyes Penales (Una Perspectiva desde el Derecho Comparado), Ed. Jurídica Continental, San José de Costa Rica, 2002.

Gómes Canotilho, Direito Constitucional, 6a ed., Ed. Almedina, Coimbra, 1993.

Häberle, Peter, "El Recurso de Amparo en el Sistema Germano Federal", en V.V. A.A. (Coord: García Belaunde y Fernández Segado), La Jurisdicción Constitucional en Iberoamérica, Dykinson, Madrid, 1997, pp. 225-282.

HäBerle, Peter, "Grundprobleme der Verfassungsgerichtsbarkeit", en V.V. A.A. (Coord: el mismo) Verfassungsgerichtsbarkeit, Darmstadt, 1976.

Huerta Guerrero, Luis Alberto, "El Proceso de Inconstitucionalidad en el Perú”, en http:// www.cajpe.org.pe/InformacionJuridica.htm

Huerta Tocildo, Susana, "El Derecho Fundamental a la Legalidad Penal”, en Revista Española de Derecho Constitucional No 39/1993.

Iniesta Delgado, Juan José y Fernández Salmerón, Manuel, "Naturaleza y Efectos de las Sentencias de Anulación Recaídos en Procesos contra Normas: La Invalidez en el Sistema Normativo y su Actuación Jurisdiccional”, en Revista Española de Derecho Constitucional $\mathrm{N}^{\mathrm{0}}$ 59-2000, pp. 35-80.

Instituto Interamericano de Derechos Humanos (Coord: Zaffaroni, Eugenio R.), Sistemas Penales y Derechos Humanos en América Latina (Informe final), Depalma, Buenos Aires, 1986.

IPSEN, JöRn, Rechtsfolgen der Verfassungswidrigkeit von Norm und Einzelakt, Baden-Baden, 1980.

Jeschex, Hans-Heinrich y Weigend, Thomas, Tratado de Derecho Penal Parte General, $5^{\text {a }}$ ed., Comares, Granada, 2002.

Jiménez Campos, Javier, “QQué Hacer con la Ley Inconstitucional?”, en AA. VV., La Sentencia sobre la Constitucionalidad de la Ley, Tribunal Constitucional-Centro de Estudios Constitucionales, Madrid, 1997, pp. 15-79.

Lascuraín Sánchez, Juan Antonio, Sobre la Retroactividad Favorable, Civitas, Madrid, 2000. 
Leone, Mauro, Il Diritto Penale nel Tempo (I, Aspetti Constituzionali del Principio di Irretroattività), Casa Editrice Dott. Eugenio Jovene, Napoli, 1980.

Martín de la Vega, Augusto, La Sentencia Constitucional en Italia, Centro de Estudios Políticos y Constitucionales, Madrid, 2003.

Moreso Mateos, José JuAn, “Sobre Normas Inconstitucionales”, en Revista Española de Derecho Constitucional $\mathrm{N}^{\circ}$ 38/1993, pp. 81-115.

Nogueira Alcalá, Humberto, "La Sentencia Constitucional en Chile: Aspectos Fundamentales sobre su Fuerza Vinculante”, en Estudios Constitucionales No1/2006, pp. 97-124.

Nogueira Alcalá, Humberto, "Elementos del Bloque Constitucional del Acceso a la Jurisdicción y Debido Proceso Proveniente de la Convención Americana de Derechos Humanos", en Estudios Constitucionales $\mathrm{N}^{\circ} 1 / 2004$, pp. 123-158.

Nogueira Alcalá, Humberto, "El Derecho a la Igualdad en la Jurisprudencia Constitucional”, en Ius et Praxis $\mathrm{N}^{\circ}$ 2, año 2, Universidad de Talca, Facultad de Ciencias Jurídicas y Sociales, Talca, Chile, 1997.

Octavio de Toledo y Ubieto, Emilio, Sobre el Concepto de Derecho Penal, Universidad Complutense de Madrid, 1981, p. 325.

Pérez Royo, Javier, Curso de Derecho Constitucional, $10^{\mathrm{a}}$ ed., Marcial Pons, Madrid/Barcelona, 2005.

Pérez Royo, Fernando, "La Aplicación Retroactiva de la Ley Penal Más Favorable en los Casos de Modificaciones en la Normativa Tributaria”, en Revista Técnica Tributaria No 43/1998, pp. $75-88$.

Requena López Sobre la Función, los Medios y los Limites de la Interpretación de la Constitución, Comares, Granada, 2001.

Rubio Llorente, Francisco, "La Jurisdicción Constitucional”, en Revista Española de Derecho Constitucional No 22/1988, pp. 9-51.

Rudolphi, Hans-Joachim, "Comentario al § 2", en AA. VV., Systematischer Kommentar zum Strafgesetzbuch, AT, (6a ed) Metzner, Frankfurt, 1997, pp. 20-31.

Santamaría Pastor, Juan, Fundamentos de Derecho Administrativo I, Editorial Centro de Estudios Ramón Areces, Madrid, 1988.

Santamaría Pastor, Juan, La nulidad de Pleno Derecho de los Actos Administrativos (contribución a una teoría de la ineficacia en el derecho público), Instituto de Estudios Administrativos, Madrid, 1972.

Schüneman, Bernd, Nulla Poena Sine Lege?, Walter de Gruyter, Berlin/New York.

Siniscalco, Marco, Irretroattività delle Leggi in Materia Penale, Dott. Giuffré Editore, Milano, 1987.

Vidales Rodríguez, Caty, La Eficacia Retroactiva de los Cambios Jurisprudenciales, Tirant Lo Banch, Valencia, 2001.

Windscheid, Bernhard, Lebrbuch des Pandektenrechts I, Frankfurt am Mein, 1887. 